\title{
Oroszország és a venezuelai válság
}

Oroszország számára a venezuelai gazdasági és politikai válság kiemelt kockázatúvá vált azzal, hogy az ellenzék vezetője, a nemzetgyülés elnöki posztját betöltő Juan Guaidó, 2019. január 23-án ideiglenes elnöknek nyilvánította magát, és ezt az Egyesült Államok egyoldalúan elismerte. Az események domináns orosz értelmezése szerint az Egyesült Államok egyoldalúan, erővel próbálja elmozdítani egy szuverén ország legitimen megválasztott vezetőjét. Arra lehet tehát számítani, hogy Oroszország minden lehetséges fórumon és eszközzel elítéli majd az Egyesült Államokat a beavatkozás miatt, és igyekszik lassítani, akadályozni Maduro hatalomvesztését.

Ezzel együtt Oroszország láthatóan elkezdte „beárazni”, hogy Venezuelában hatalomváltásra kerülhet sor. Rövid távon Moszkva az átmenet menedzselésére törekszik, remélve, hogy valamilyen formában meg tudja örizni legalább a befolyása egy részét. Hosszú távon pedig arra lehet számitani, hogy Oroszország a nyugati közösség egyoldalú beavatkozását hivatkozási alapként fogja használni, ezzel legitimálva saját, a nemzetközi rendet sértő múltbéli és esetleges jövőbeli lépéseit. Ilyen értelemben a venezuelai változások jelentősége messze túlmutat Dél-Amerikán, és a nemzetközi politika intézményes garanciáinak további gyengülése felé mutat.

Kulcsszavak: Oroszország, Venezuela, Egyesült Államok, Maduro, Guaidó, Wagner csoport

\section{Rácz András: Russia and the Crisis in Venezuela}

The economic and political crisis in Venezuela have become a key risk factor for Russia. On 23 January 2019 Juan Guaidó, President of the National Assembly has declared himself interim president and the United States unilaterally recognized this. According to the dominant Russian narrative of the events, the United States tries to unilaterally and forcefully remove the legitimately elected leader of a sovereign country. Hence, it is very likely that Russia will condemn the U.S. on all possible for it, and will try to slow down, or prevent Maduro's loss of power.

Nevertheless, Russia apparently started to play on the possibility of a regime change in Venezuela. In the short run, Moscow strives for managing the transition process, while hoping that at least parts of its earlier influence can be preserved. In the long run, one may expect that Russia will use the unilateral intervention of the West in Venezuela as a reference point, in order to legitimise its own steps that violated the international order or will do so in the future. From this perspective, the importance of the changes in Venezuela way exceeds Latin America, and points towards the further weakening of the institutional guarantees, on which the international system has been based.

Keywords: Russia, Venezuela, United States, Maduro, Guaidó, Wagner Group

\footnotetext{
1 A cikk alapjául szolgáló kutatás a Nemzeti Kutatási, Fejlesztési és Innovációs Hivatal 129243-as számú, „Hagyomány és rugalmasság Oroszország biztonság-és védelempolitikájában” címü kutatási pályázatának támogatásával valósult meg.
} 


\section{Venezuela fontossága Oroszország számára}

Oroszország több okból is kiemelt figyelemmel követi a venezuelai eseményeket. A legfontosabb az a nagystratégiai megfontolás, hogy az erős baloldali hagyományokkal rendelkező Venezuela Hugo Chávez 1998. decemberi hatalomra kerülése óta megbízható szövetségese Oroszországnak az Egyesült Államokkal szemben, elsősorban Dél-Amerikában, de az ENSZ-ben és az olajtermelö országok között is. Venezuela azon néhány ország közé tartozik, amelyek még Abházia és Dél-Oszétia Grúziától való, Oroszország által kikényszerített „függetlenedését” is elismerték 2008-ban.

A Washington ellenében egyértelműen Oroszország, illetve Kína felé orientálódó venezuelai külpolitikában nem hozott változást Chávez 2013-as halála és Nicolás Maduro hatalomra kerülése sem. A stratégiai érdekek változatlanságán túl a változás ellen hatott az is, hogy Maduro 2006 és 2013 között Hugo Chávez külügyminisztereként szolgált.

Venezuela az elmúlt két évtizedben az orosz hadiipar kiemelt vásárlója is lett. Chávez hatalomra kerülése óta Caracas több mint tizenkét milliárd dollár (!) értékben szerzett be orosz fegyvereket mind a szárazföldi erők, mind a légierő, mind a légvédelem számára. A Stockholm International Peace Research Institute (SIPRI) ${ }^{2}$ adatai szerint a szárazföldi erők számára Venezuela majdnem száz T-72-es harckocsit, 123 BMP-3 és 114 BTR-80 gyalogsági harcjármüvet, valamint több tucatnyi önjáró löveget és nehéz aknavetőt vásárolt, a légierőt pedig 24 darab Szuhoj Szu-30 többfeladatú vadászbombázó repülőgéppel, továbbá $38 \mathrm{Mi}-8 / 17$ és két Mi-26 katonai szállító helikopterrel, valamint 10 Mi-35 támadó helikopterrel erősítették meg. A katonai kapcsolatoknak kulcseleme volt a venezuelai légvédelem megerősítése, deklaráltan egy esetleges amerikai támadás elhárítása érdekében. Így 1998 és 2018 között Oroszország (részben Fehéroroszországon keresztül) leszállított 250 BUK-M2 légvédelmi rakétarendszert, 200-nál több Sz-300 légvédelmi rendszert, 550 modernizált SzA-3B Nyeva légvédelmi rakétát és négyezer Igla-24 vállról indítható légvédelmi rakétát is.

A Rosszijszkaja Gazeta orosz kormánylap 2019. február elején arról számolt be, hogy a BMP-3 lett a venezuelai szárazföldi erők fő gyalogsági harcjármüve, ezzel pedig Venezuela az első olyan latin-amerikai ország, amelyik rendszerbe állítja a típust. ${ }^{3}$ Látható tehát, hogy az orosz hadiipar számára Venezuela nemcsak mint piac, hanem mint referencia is fontos a világ más részein tervezett fegyvereladásokhoz.

Oroszország számára gazdasági és pénzügyi szempontból is kulcsfontosságú a venezuelai helyzet alakulása, Moszkva ugyanis Caracas egyik legfontosabb támogatója és hitelezöje. Legnagyobb részben a Rosznyefty orosz állami olajvállalat, kisebb részben pedig maga az orosz állam összesen több mint tizenhét milliárd (!) dollárnyi hitelt és támogatást biztosított Venezuelának az elmúlt években. Ezért cserébe a Rosznyefty több venezuelai olajmezőben is részesedést szerzett, továbbá bekapcsolódott egy gázlelőhely-keresési projektbe is. Emellett a Rosznyefty a legutóbbi, másfél milliárd dolláros hitel fedezeteként megkapta a Petroleos de Venezuela (PDVSA) Citgo nevü, az Egyesült Államokban működő leány- 
vállalatának 49,9\%-át is. A Rosznyefty 2019. február eleji adatai szerint a PDVSA-nak azzal, hogy kitermelési lehetőséget adott a Rosznyeftynek, sikerült a 2018 elején fennálló, összesen 4,6 milliárd dolláros adósságát az év végére a felére, 2,3 milliárd dollárra csökkentenie. ${ }^{4}$ $\mathrm{Az}$ orosz olajvállalat nem mulasztotta el leszögezni, hogy szerintük minden venezuelai szerződésük teljesen törvényes és tevékenységük a jogszabályokkal összhangban zajlik.

Ami az orosz államot illeti, Venezuela lassan egy évtizede tartó súlyos gazdasági problémái miatt 2017-ben megállapodás született az akkor Oroszország felé fennálló, 3,15 milliárd dollárra rúgó államadósság tíz évre szóló átstrukturálásáról, amelynek keretében az első hat esztendőben csak nagyon alacsony részleteket kell törleszteni. A következö, százmillió dolláros részlet 2019. március végén volna esedékes. A jelenlegi helyzettel, így a soros törlesztéssel kapcsolatos orosz bizonytalanságokat jól mutatja Szergej Sztorcsak pénzügyminiszter-helyettes 2019. január 29-i nyilatkozata: „Valószínűleg probléma lesz. [...] A szuverén adós akkor nem fizet, ha vagy nem akar, vagy nem tud. Ha nem tud, az csőd. Ha nem akar, az politika."5 Sztorcsak egyszerre szórakoztató és némileg tanácstalan nyilatkozata szintén azt jelezheti, hogy Moszkva hatalomváltásra számít, és a hazai közvélemény felkészítésével igyekszik minimalizálni a várható anyagi kár által okozott politikai veszteséget. Guaidó ideiglenes elnök valószínűleg épp az orosz és kínai befektetők aggodalmaira reagált, amikor kijelentette, hogy hatalomra kerülése esetén minden szerződést tiszteletben fog tartani. ${ }^{6}$

\section{Orosz lépések a válság kezelésére}

Moszkva diplomáciai és politikai eszközökkel a venezuelai tiltakozások kezdetétől fogva látványosan támogatja Nicolás Madurót. Ebbe a sorba illeszkedett több, az ENSZ-ben tett nyilatkozat és számos más deklaráció is. Emellett az elmúlt év decemberében Oroszország demonstratív céllal Venezuelába küldött két Tupoljev Tu-160-as, nukleáris fegyver hordozására is alkalmas hadászati bombázót, egy Antonov An-124-es nehéz szállító-repülőgép és egy Iljusin Il-62-es utasszállító kíséretében.

Azzal azonban, hogy az ellenzék vezetője, a nemzetgyülés elnöki funkcióját betöltő Juan Guaidó 2019. január 23-án az ország elnökének nyilvánította magát, és azt az Egyesült Államok elismerte, az eddig „csak” feszült venezuelai helyzet hirtelen válságosra fordult Moszkva számára. Ettől fogva vált reális veszéllyé ugyanis, hogy Maduro valóban, és esetleg igen gyorsan elveszítheti a hatalmát.

Vlagyimir Putyin orosz elnök rögtön másnap támogatásáról biztosította Madurót, élesen elítélve az Egyesült Államokat a venezuelai belpolitikába való beavatkozás miatt, az orosz külügyminisztérium pedig felajánlotta, hogy Moszkva kész közvetíteni a felek között. Az orosz diplomácia azóta is minden csatornán a helyzet békés rendezését szorgalmazza, és kiáll Venezuela szuverenitásának védelme mellett. A Kreml szóvivője, Dmitrij

Veneszuelszkaja PDVSA sznyizila dolg pered «Rosznyeftyu» v dva raza, [online], 2019. 02. 05. Forrás: RBK [2019. 02. 07.] V Minfinje RF ocenyili sanszü polucsity ot Veneszuelü vüplatü po vnyesnyemu dolgu, [online], 2019. 01. 29. Forrás: Interfax [2019. 02. 07.]

6 Guaidó tries to win support of Maduro allies Russia and China, [online], 2019. 02. 01. Forrás: The Hindu [2019. 02. 07.] Telefonnüj razgovor sz Prezigyentom Veneszueli Nikolaszom Maduro, [online], 2019. 01. 24. Forrás: Kremlin.ru [2019. 02. 07.] 
Peszkov egyértelmüen fogalmazott: Moszkva számára Guaidó továbbra is a venezuelai parlament házelnöke, és nincs szó arról, hogy elismernék az ország ideiglenes államföjének. ${ }^{8}$

Oroszország természetesen tisztában van vele, hogy a diplomáciai eszközökön túl erősen korlátozottak a lehetőségei a venezuelai belső folyamatok érdemi befolyásolására, és főleg a megfordításukra. Az ország földrajzilag túlságosan messze van Oroszországtól, a legközelebbi orosz katonai bázis is körülbelül tízezer kilométer távolságban, Szíriában van. A diplomáciai eszköztár ereje is jelentősen beszükült azzal, hogy az Egyesült Államok példáját nemcsak a legtöbb dél-amerikai ország követte, ideértve elsőként Brazíliát, de január 31-én az Európai Parlament is elismerte Guaidót az ország ideiglenes elnökének. Ettől kezdve Oroszország reálisan csak arra törekedhet, hogy igyekezzen menedzselni a várható átmenetet, a lehető legtöbbet megőrizve a befolyásából, politikai és gazdasági érdekeiből.

Február 6-án a Bloomberg már arról írt, hogy Oroszország egyre kevésbé hisz abban, hogy Maduro hatalmon tud maradni. A lap idézte Vlagyimir Dzsabarovot, az orosz parlament felsőháza külügyi bizottságának elnökhelyettesét, aki nyíltan úgy fogalmazott, hogy „az idő sajnos nem Madurónak dolgozik.”9 A Kreml szóvivője természetesen hevesen cáfolta, hogy megváltozott volna az orosz álláspont, ${ }^{10}$ Dzsabarov viszont nem vonta vissza a nyilatkozatát. Ugyanezen a napon Venezuela Oroszországba akkreditált nagykövete kijelentette, hogy Caracas szeretné felkérni Moszkvát, hogy közvetítőként segítse a válság rendezését. ${ }^{11} \mathrm{Az}$, hogy a két héttel korábbi, akkor válasz nélkül maradt orosz közvetítési ajánlatot a venezuelai vezetés végül elfogadta, azt mutatja, hogy a Maduro-kormányzat is úgy értékeli, hogy a helyzetet önállóan már nem tudja megoldani.

\section{A Wagner Csoport Venezuelában}

A nyugati és az orosz sajtóban már 2019. január közepén felmerült, ${ }^{12}$ hogy Moszkva a Wagner Csoport nevü, ${ }^{13}$ orosz katonai magánvállalat 400 zsoldosát Venezuelába küldte, hogy segítse Madurót a hatalom megtartásában és az egyre kiterjedtebb ellenzéki tiltakozások elleni fellépésben. Müveleti szempontból egyáltalán nem bonyolult a Wagner néhány száz harcosát Venezuelába telepíteni, különösen akkor, ha csak kézi- és könnyüfegyvereket visznek magukkal.

A Wagner bevetésére vonatkozó újságírói kérdésre válaszolva Jurij Boriszov, a védelmi ipari komplexumért is felelős orosz miniszterelnök-helyettes 2019. január 31-én kijelentette,

8 Dmitrij Szmirnov: Putyin obszugyil sz Szovbeszom Karakasz i Vasington, [online], 2019. 02. 01. Forrás: Komszomolszkaja Pravda [2019. 02. 07.]

9 Henry Meyer - Ilya Arkhipov, Russia Starts to Worry Maduro’s Grip May Slip in Venezuela, [online], 2019. 02.06. Forrás: Bloomberg [2019. 02.07.]

10 Kira Latuhina: V Kremlje nye peresztali podgyerzsivaty Maduro, [online], 2019. 02. 07. Forrás: Rosszijszkaja Gazeta [2019. 02.07.]

11 Jurij Kovalov: Veneszuela vüsztupila za poszrednyicsesztvo Rosszii v uregulirovanyii krizisza, [online], 2019. 02.06. Forrás: Rosszijszkaja Gazeta [2019. 02. 07.]

12 Maria TsvetKova - Anton Zverev: Exclusive: Kremlin-linked contractors help guard Venezuela's Maduro - sources, [online], 2019. 01. 25. Forrás: Reuters [2019. 02.07.]

13 HART Endre: Az orosz katonai magánvállalatok és a Wagner Csoport szerepe, illetve müködése, [online], Nemzet és Biztonság, 12. évf., 2018/2, 44-56. o. 
hogy Venezuela területén nem tartózkodnak orosz katonák. ${ }^{14}$ Lényeges elem azonban a nyilatkozat szóhasználata, Boriszov ugyanis vojennoszluzsajsije-röl beszélt, ami az orosz terminológiában a hivatásos katonákat jelenti. A Wagner állománya azonban formálisan nem tartozik ide (annak ellenére sem, hogy a szervezet roppant szorosan kötődik az orosz katonai hírszerzéshez, a GRU-hoz), így alkalmazottai sem számítanak vojennoszluzsajsije-nek. Másképp fogalmazva tehát Boriszov irreleváns választ adott a kérdésre, hiszen csak annyit állított, hogy orosz katonák nincsenek Venezuelában, arról azonban nem mondott semmit, hogy a Wagner katonai magánvállalat alkalmazottai jelen vannak-e az országban.

Érdemes azonban tisztában lenni az orosz segítségnyújtás műveleti korlátaival. Néhány száz Wagner alkalmazott természetesen nem képes rá, hogy ellenőrzése alatt tartsa a Magyarországnál majdnem tízszer nagyobb területü, körülbelül harmincmillió fös lakosságú Venezuelát. Annál is kevésbé, mert a Wagner korábban sosem hajtott végre műveletet Dél-Amerikában, így nem rendelkezik sem helyismerettel, sem érdemi mennyiségü, spanyolul beszélő alkalmazottal. Az sem reális, hogy az orosz zsoldosok jelentős befolyást tudnának gyakorolni a katonai erőviszonyokra, ugyanis Venezuelában csak a hadsereg létszáma meghaladja a félmillió föt, és ehhez jönnek még belügyminisztériumi és más alárendeltségben működő reguláris és paramilitáris alakulatok.

A Wagner zsoldosai arra azonban minden bizonnyal alkalmasak, hogy szavatolják Maduro személyes biztonságát az átmeneti időszakban még abban az esetben is, ha a venezuelai biztonsági szervek egy részének lojalitása meginogna. Képesek emellett arra is, hogy a válság eszkalálódása esetén biztosítsák - vagy legalábbis megkíséreljék biztosítani -, hogy Maduro menedzselt módon távozzon az országból. Kézenfekvő lehet az analógia Viktor Janukovics 2014-ben megbukott ukrán elnökkel, aki szintén orosz segítséggel tudott elmenekülni Ukrajnából, elkerülve a felelősségre vonást, miközben nem mellesleg sokmillió dollár értékủ vagyont vitt magával készpénzben, aranyban és más értéktárgyakban.

\section{Orosz szakértői értékelések}

$\mathrm{Az}$ orosz biztonság- és védelempolitikai szférához erősen kötődö15 Orosz Stratégiai Tanulmányok Intézetének (Rosszijszkij Insztyitut Sztrategicsesszkih Isszledovanyii, RISzI) helyzetértékelését is az amerikai beavatkozás narratívája határozza meg. Az intézetvezető Dél-Amerika szakértője, Igor Psenyicsnyikov egy nappal Guaidó nyilatkozata után, január 24-én úgy nyilatkozott a TASSZ orosz hírügynökségnek, hogy az Egyesült Államok kész a polgárháborúig is élezni a helyzetet, ha Maduro nem távozik a hatalomból. Psenyicsnyikov szerint az események „klasszikus színes forradalmi” forgatókönyv szerint zajlanak, ahol az információs eszközök és a propaganda meghatározó szerepet játszik abban, hogy a tömegek az utcára mentek. Ha pedig polgárháborúra kerülne sor, az ürügyül szolgálhatna arra, hogy az Egyesült Államok békefenntartó erőket küldjön az országba. ${ }^{16}$

14 Vice-Premjer Boriszov otverg nalicsije rosszijszkih vojennüh v Veneszuelje, [online], 2019. 01. 31. Forrás: RBK [2019. 02. 07.]

15 Az intézet igazgatóját, Leonyid Resetnyikovot nemrégiben hivatalában fogadta Vlagyimir Putyin orosz elnök. Vsztrecsa sz Mihailom Fradkovüm i Leonyidom Resetnyikovüm, [online], 2019. 01. 31. Forrás: Kremlin.ru [2019. 02. 07.]

16 SzSA budut raszkacsivaty szituaciju v Veneszuelje do uhoda Maduro ili vojnü - ekszpert RISzI, [online], 2019. 02. 03. Forrás: Rosszijszkij Insztyitut Sztrategicsesszkih Isszledovanyii [2019. 02. 07.] 
Miután január végére nyilvánvalóvá vált, hogy Maduro nem fog magától távozni a hatalomból, Psenyicsnyikov január 29-én úgy értékelte a helyzetet, hogy „megbukott az amerikai államcsíny-kísérlet". ${ }^{7}$

Kevésbé direkten fogalmazva, de hasonló következtetésre jutott a RISzI egy másik munkatársa, Dmitrij Burih is. Burih szerint az ellenzék vezetője, Guaidó korábban nem volt különösebben ismert vagy befolyásos figura, és nincs meg az eleve széttagolt ellenzék vezetéséhez szükséges támogatottsága. Valószínübb, hogy csak egyfajta faltörő kosként (taran) használják - hogy kik, azt Burih homályban hagyja -, hogy végrehajtsa az államcsínyt, és utána rövid időn belül távozzon a hatalomból. ${ }^{18}$ Elemzésében Burih azzal számol, hogy Maduro hatalmon maradásának kulcsa a hadsereg lojalitásának megőrzése. Ha azonban ez meggyengül, akkor igen valószínü, hogy az elnök távozni kényszerül. Érdemes észrevenni, hogy a venezuelai események leírására mindkét szakértő konzekvensen az államcsíny (goszperevorot) kifejezést használta, ami, figyelembe véve a RISzI kötődéseit, az orosz hivatalos álláspont indikátorának tekinthető.

Az amerikai motivációk között az orosz államhoz kötődő értékelések szerint meghatározó fontosságú a venezuelai olajszektor feletti ellenőrzés megszerzésének szándéka. Ezen a véleményen van mind a RISzI térséggel foglalkozó szakértője, a fentebb említett Burih, ${ }^{19}$ a Rosszijszkaja Gazeta nevü kormánylap, valamint a szintén rendszerhü Komszomolszkaja Pravda napilap Venezuelába küldött tudósítója is. ${ }^{20}$

Az olajipari aspektusokon túl Moszkva kiemelt figyelemmel követi a Caracas ellen bevezetett amerikai szankciókat is. Ivan Tyimofejev, az Orosz Nemzetközi Kapcsolatok Tanácsának igazgatóhelyettese értékelése szerint az egyre erősebb amerikai szankciók a venezuelai hatalomváltás előjeleinek tekinthetők, és jól mutatják a Venezuelával szembeni amerikai külpolitika prioritásait. ${ }^{21}$ Tyimofejev arra is rámutat, hogy a kezdeti, 2014-től bevezetett amerikai büntetőintézkedések még nem voltak súlyosak. Valóban komoly károkat okozó szankciókat csak a Trump-adminisztráció vezetett be 2017-től kezdődően, hozzátéve, hogy mivel az újabb és újabb, erősebb szankciók bevezetése egybeesett az olajárak erőteljes fluktuációjával, igen nehéz pontosan megállapítani, hogy maguk a szankciók mennyiben felelősek a venezuelai gazdaság nehézségeiért. Tyimofejev arra a következtetésre jut, hogy ha Venezuelában végül hatalomváltás következik be, az erős érv lesz az amerikai külpolitika számára, hogy a későbbiekben is intenzíven használjanak gazdasági szankciókat külpolitikai célok elérése érdekében.

Jelentős figyelmet kap az orosz sajtóban a venezuelai aranykészlet sorsa, és mindazon nehézségek, amelyekkel Caracas az arany értékesítése során szembesül. A kérdés azután vált aktuálissá, hogy a Bank of England megtagadta, hogy átadja a Maduro-kormánynak a Nagy-Britanniában őrzött, 1,2 milliárd dollárnyi aranyat. Az RBK orosz hírportál idézi

17 Goszperevorot v Veneszuelje zabukszoval, [online], 2019. 01. 29. Forrás: Rosszijszkij Insztyitut Sztrategicsesszkih Isszledovanyii [2019.02.07.]

18 Dmitrij Nyikolajevics Burin: Ekszpert RISzI: Nyefty - ogyin iz kljucsevüh motivov usztremlenyii SzSA v Veneszuelje, [online], 2019. 01. 30. Forrás: Rosszijszkij Insztyitut Sztrategicsesszkih Isszledovanyii [2019. 02. 07.]

19 Uo.

20 Alekszandr Koc - Anton Fokin: SzSA hotyjat vernuty kontrol' nad veneszuelszkoj nyeftyju, [online], 2019. 01.29. Forrás: Komszomolszkaja Pravda [2019. 02. 07.]

21 Ivan Tyimofejev: Are US Sanctions Against Venezuela a Regime Change Precursor?, [online], 2019. 01. 27. Forrás: Russian International Affairs Council [2019. 02. 07.] 
a VTB Bank vezetőjét, Andrej Kosztyint, aki egyértelmüen jogtalannak nevezte a Bank of England eljárását, hozzátéve a venezuelai folyamatok kapcsán, hogy „nem lehet csak úgy fogni és megválasztatni egy új elnököt”."22 Véleménycikkében Oleg Sibanov, a moszkvai Orosz Gazdasági Iskola nevü egyetem pénzügytan professzora veszélyes precedensnek tartja a Bank of England eljárását, különösen azért, mert az aranykészletet annak ellenére nem adták át, hogy a brit kormány nem ismerte el Guaidót elnöknek. ${ }^{23}$

\section{Stratégiai következmények}

Oroszország számára a folyamatban lévő venezuelai hatalomváltás azzal fenyeget, hogy elveszíti a kubai nyitás után megmaradt utolsó latin-amerikai szövetségesét is. Ezzel Moszkva regionális és globális pozíciói egyaránt gyengülnének, hiszen Venezuela volt az egyik utolsó olyan ország, amelyre mindig számíthatott az ENSZ-ben és az olajtermelő államok között egyaránt.

$\mathrm{Az}$ orosz vezetés azzal is tisztában van, hogy Venezuelában nem képesek megismételni a szíriai forgatókönyvet. A katonai segítségnyújtás az evidens földrajzi-logisztikai problémákon túl azért sem reális lehetőség, mert a latin-amerikai térséget az Egyesült Államok a saját, kiemelt érdekszférájának tekinti, így ott egy orosz beavatkozás sokkal komolyabb nehézségekbe ütközne, mint Szíriában. Moszkva tehát nem képes katonai erővel hatalomban tartani Madurót; a január végi orosz közvetítési ajánlat lényegében ennek beismerése volt.

Ami a stratégiai kilátásokat illeti, a Caracasban zajló folyamatok domináns orosz értelmezése az, hogy az Egyesült Államok egyoldalú beavatkozással kívánja elmozdítani egy szuverén ország legitimen megválasztott vezetőjét. Ez pedig Moszkva szerint illeszkedik abba a sorba, amit az amerikai külpolitika az 1999-es, ENSZ-felhatalmazás nélküli koszovói beavatkozással kezdett és a 2003-as iraki háborúval folytatott. Ebbe a láncba az orosz hatalmi elit perspektívájából ugyanúgy beleillenek a posztszovjet térség „színes forradalmai”, mint az „arab tavasz” eseményei, legfontosabbként pedig a 2014-es ukrajnai fordulat.

Moszkva számára a fentieken túl azért is lényegesek a venezuelai események, mert érzékelhetően arra számítanak, hogy az Egyesült Államok és a nyugati világ a Maduro ellen bevetett eszközöket később máshol is alkalmazhatja, adott esetben Oroszországgal szemben is. Ebből a szempontból nemcsak Juan Guaidó gyors, egyoldalú nyugati elismerése és a gazdasági szankciók szolgálhatnak fontos tanulságokkal, de azok a nehézségek is, amelyekkel Caracas az aranykészletének pénzzé tétele során szembesül.

Nem várható tehát, hogy Moszkva könnyen elfogadná a venezuelai változásokat, azzal együtt, hogy a folyamatokat nem tudja megfordítani. Az orosz állam minden rendelkezésére álló csatornát és eszközt felhasznál majd arra, hogy elítélje a Nyugatot, és föképp az Egyesült Államokat az egyoldalú beavatkozásért. Ezzel ugyanis Moszkva egyrészt erősítheti saját alkupozícióját a venezuelai átmenet folyamatában, politikai-gazdasági koncessziókat remélve az új vezetés elismeréséért. Másrészt, a venezuelai események folyamatos, erőteljes elítélése azt is lehetővé teszi Oroszország számára, hogy a későbbiekben

\footnotetext{
2 Kosztyin nazval beszpregyelom areszt Bankom Anglii zolota Veneszuelü, [online], 2019. 02. 04. Forrás: RBK [2019. 02. 07.]

23 Oleg Sibanov: Zolotoje pravilo: pocsemu risenyije Banka Anglii - opasznüj precedent?, [online], 2019. 01. 30. Forrás: RBK [2019. 02.07.]
} 
az Egyesült Államok beavatkozását hivatkozási alapként használja, ezzel legitimálva saját, a nemzetközi rendet sértő múltbéli és esetleges jövőbeli lépéseit. Ilyen értelemben a venezuelai változások jelentősége messze túlmutat Dél-Amerikán, és a nemzetközi rendszer intézményes kereteinek további gyengülését vetíti előre.

\section{FELHASZNÁLT IRODALOM}

Bruszilov, Alekszej - Mojszejev, Alekszej: Rosszijszkaja BMP-3 sztala osznovnoj bojevoj masinoj pehotü armii Veneszuelü, [online], 2019. 02. 07. Forrás: Rosszijszkaja Gazeta [2019. 02. 07.]

BurIH, Dmitrij Nyikolajevics: Ekszpert RISzI: Nyefty - ogyin iz kljucsevüh motivov usztremlenyii SzSA v Veneszuelje, [online], 2019. 01. 30. Forrás: Rosszijszkij Insztyitut Sztrategicsesszkih Isszledovanyii [2019. 02. 07.]

Goszperevorot v Veneszuelje zabukszoval, [online], 2019. 01. 29. Forrás: Rosszijszkij Insztyitut Sztrategicsesszkih Isszledovanyii [2019. 02. 07.]

Guaidó tries to win support of Maduro allies Russia and China, [online], 2019. 02. 01. Forrás: The Hindu [2019. 02. 07.]

HART Endre: Az orosz katonai magánvállalatok és a Wagner Csoport szerepe, illetve működése, [online], Nemzet és Biztonság, 12. évf., 2018/2, 44-56.

Koc, Alekszandr - FoKIn, Anton: SzSA hotyjat vernuty kontrol' nad veneszuelszkoj nyeftyju, [online], 2019.

01. 29. Forrás: Komszomolszkaja Pravda [2019. 02. 07.]

Kosztyin nazval beszpregyelom areszt Bankom Anglii zolota Veneszuelü, [online], 2019. 02. 04. Forrás: RBK [2019. 02. 07.]

Kovalov, Jurij: Veneszuela vüsztupila za poszrednyicsesztvo Rosszii v uregulirovanyii krizisza, [online], 2019. 02. 06. Forrás: Rosszijszkaja Gazeta [2019. 02. 07.]

Latuhina, Kira: V Kremlje nye peresztali podgyerzsivaty Maduro, [online], 2019. 02. 07. Forrás: Rosszijszkaja Gazeta [2019. 02. 07.]

Meyer, Henry - Arkhipov, Ilya: Russia Starts to Worry Maduro's Grip May Slip in Venezuela, [online], 2019. 02. 06. Forrás: Bloomberg [2019. 02. 07.]

Telefonnüj razgovor sz Prezigyentom Veneszueli Nikolaszom Maduro, [online], 2019. 01. 24. Forrás: Kremlin.ru [2019. 02. 07.]

Vsztrecsa sz Mihailom Fradkovüm i Leonyidom Resetnyikovüm, [online], 2019. 01. 31. Forrás: Kremlin.ru [2019. 02.07.]

Sibanov, Oleg: Zolotoje pravilo: pocsemu risenyije Banka Anglii - opasznüj precedent?, [online], 2019. 01. 30. Forrás: RBK [2019. 02. 07.]

SIPRI Arms Transfers Database, [online], 2019. 02. 07. Forrás: Sipri.org [2019. 02. 07.]

Szmirnov, Dmitrij: Putyin obszugyil sz Szovbeszom Karakasz i Vasington, [online], 2019. 02. 01. Forrás: Komszomolszkaja Pravda [2019. 02. 07.]

SzSA budut raszkacsivaty szituaciju v Veneszuelje do uhoda Maduro ili vojnü - ekszpert RISzI, [online], 2019. 02. 03. Forrás: Rosszijszkij Insztyitut Sztrategicsesszkih Isszledovanyii [2019. 02. 07.]

Tsvetkova, Maria - Zverev, Anton: Exclusive: Kremlin-linked contractors help guard Venezuela's Maduro - sources, [online], 2019. 01. 25. Forrás: Reuters [2019. 02. 07.]

Tyimofejev, Ivan: Are US Sanctions Against Venezuela a Regime Change Precursor?, [online], 2019. 01. 27. Forrás: Russian International Affairs Council [2019. 02. 07.]

V Minfinje RF ocenyili sanszü polucsity ot Veneszuelü vüplatü po vnyesnyemu dolgu, [online], 2019. 01.29. Forrás: Interfax [2019. 02. 07.]

Veneszuelszkaja PDVSA sznyizila dolg pered «Rosznyeftyu» v dva raza, [online], 2019. 02. 05. Forrás: RBK [2019. 02. 07.]

Vice-Premjer Boriszov otverg nalicsije rosszijszkih vojennüh v Veneszuelje, [online], 2019. 01. 31. Forrás: RBK [2019. 02.07.] 